\title{
Occurrence of Lysiphlebus testaceipes parasitizing Aphis gossypii in watermelon in the State of Rio Grande do Norte, Brazil
}

\author{
Ocorrência de Lysiphlebus testaceipes parasitando Aphis gossypii em melancia, no Estado do Rio \\ Grande do Norte, Brasil
}

\section{Luciano Pacelli Medeiros Macedo ${ }^{\mathrm{I}}$ Edmondson Reginaldo Moura Filho $^{\mathrm{I}}$ Adriano Soares Carvalho Carlos Eduardo Souza Bezerra ${ }^{\text {II }}$ Luís Cláudio Paterno Silveira ${ }^{\text {II }}$}

\section{- NOTE -}

\begin{abstract}
This is the first report of the parasitoid Lysiphlebus testaceipes (Cresson) as a biological control agent of the aphid Aphis gossypii Glover in watermelon crop in Vale do Açu, RN. It was observed that near the harvest, almost all collected aphids were mummified, and after analyzing the emerged parasitoids, the parasitoid L. testaceipes was identified. Therefore, in the future, this species may be included in A. gossypii integrated management programs.
\end{abstract}

Key words: aphid, biological control, Citrullus lanatus, insects pest.

\section{RESUMO}

Este é o primeiro relato do parasitoide Lysiphlebus testaceipes (Cresson) como agente de controle biológico do pulgão Aphis gossypii Glover na cultura da melancia, na região do Vale do Açu, Rio Grande do Norte (RN). Observou-se que próximo da colheita quase todos os pulgões coletados encontravam-se mumificados e, na análise dos parasitoides emergidos, constatou-se o parasitismo por L. testaceipes. Essa espécie, portanto, poderá ser incluída em um programa de manejo integrado de A. gossypii futuramente.

Palavras-chave: afídeo, controle biológico, Citrullus lanatus, inseto-praga.

Watermelon, Citrullus lanatus, is one of the most important cultivated cucurbits in the world. In Brazil, the largest producers are the states of Rio Grande do Sul, São Paulo, Bahia, Rio Grande do Norte and
Tocantins, which contribute about $60 \%$ of the national production (AGRIANUAL, 2007). The region of Vale do Açu is the main production area of watermelon in Rio Grande do Norte, but faces some limitations due to phytosanitary problems, which negatively influence its production. Among the factors that have contributed to it is the attack of insect pests such as aphids.

According to BUENO (2005), aphids are serious pests in various crops, both in field and greenhouse. The specie Aphis gossypii Glover, 1877 (Hemiptera: Aphididae) is found on all continents (PEÑA-MARTINEZ, 1992), attacking various crops such as cotton, melon, watermelon, pepper, cucumber, potato, cashew, tomato and ornamental plants (FERNANDES et al., 2001). However, there are natural enemies of insect pests, such as the solitary endoparasitoid Lysiphlebus testaceipes (Cresson, 1880) (Hymenoptera: Braconidae, Aphidiinae) (RODRIGUES \& BUENO, 2001; CARNEVALE et al., 2003), which also can use other species of aphids as hosts (STARÝ et al., 1993).

In the Brazilian literature there are no surveys of aphid parasitoids in the Central West, North and Northeast regions. However, STARÝ et al. (2007) evaluates the relationship parasitoid-aphid-plant in Brazil and provide a useful data bank for subsequent studies on aphid parasitoids ecology and aphid

'Laboratório de Biotecnologia, Instituto Federal de Educação, Ciência e Tecnologia do Rio Grande do Norte (IFRN), Campus Ipanguaçu, 59508-000, Ipanguaçu, RN, Brasil. E-mail: luciano.macedo@ifrn.edu.br. *Autor para correspondência.

IIDepartamento de Entomologia, Universidade Federal de Lavras (UFLA), Lavras, MG, Brasil. 
management. They have recorded the occurrence of $\boldsymbol{L}$. testaceipes parasitizing A. gossypii in the states of Minas Gerais, Parana and São Paulo in various cultures, and in the cotton cultivation in two states in the Northeast (Bahia and Pernambuco).

Due to the scarcity of information in this respect, the objectives of this study were to identify the aphid species that attacks the watermelon crop in the Vale do Açu, RN, and identify the parasitoid species responsible for natural biological control in this region, since there are no records in the literature on this issue.

The study was conducted from November to December 2009, performing weekly samplings of aphid infested watermelon leaves in plantings located at the Instituto Federal de Educação, Ciência e Tecnologia of Rio Grande do Norte (IFRN) / Ipanguaçu Campus, RN (3651'22" S, 530'45" W, 20m altitude). Weekly, 100 leaves were randomly collected and taken to the IFRN Biotechnology Laboratory, where they were placed in an acrylic cage $(50 \times 50 \times 50 \mathrm{~cm})$, the sides covered with voile fabric. The cage was kept at ambient temperature and photoperiod (in average 25,5 degrees and 12 hours photophase), observing the daily emergence of parasitoids, which were sent to Dr Luís Cláudio Paterno Silveira, Department of Entomology, Universidade Federal de Lavras (UFLA), MG, together with aphid samples for identification. The material was deposited in the Entomological Collection of this Department, and also in the of IFRN Biotechnology Laboratory and in Applied Biological Control Laboratory, Universidade Federal Rural do Semi-Árido (UFERSA) in Mossoró, RN.

A single species of aphid, $\boldsymbol{A}$. gossypii was found. The observations showed a preference of the aphid for the underside of the watermelon leaves, but nymphs and adults were found on the upper side of the leaves. The presence of winged and wingless individuals at different stages was noticed, in a high population, since all the leaves were being attacked by the aphid. According to FERNANDES et al. (2001), the winged forms appear more often in high infestation densities, when the competition for food is high.

Near harvest, however, $90 \%$ of the collected aphids were parasitized (mummified) by the species identified as $\boldsymbol{L}$. testaceipes, the only parasitoid found, and which is regarded as a promising biological control agent for several species of aphids (RODRIGUES et al., 2003). According to RODRIGUES \& BUENO (2001), A. gossypii was suitable for the development of $\boldsymbol{L}$. testaceipes with a parasitism rate of $56 \%$ and $83 \%$ of emergence. CARNEVALE et al. (2003) found a parasitism of $44 \%$, considered satisfactory, and emergence of $93 \%$.
In the Northeast, SOUZA et al. (2003) and FERNANDES et al. (2000), in Bahia and Pernambuco, respectively, reported the occurrence of $\boldsymbol{L}$. testaceipes parasitoid in cotton, parasitizing $\boldsymbol{A}$. gossypii, but not studied the parasitism rate and percentage of emergence in this association.

The present study demonstrated that there is potential for using the parasitoid L. testaceipes as a biological control strategy in IPM of $\boldsymbol{A}$. gossypii, but further study would be needed for confirmation in different seasons and a longer sampling period.

\section{REFERENCES}

AGRIANUAL - Anuário da Agricultura Brasileira. São Paulo: Instituto FNP, 2007. 520p.

BUENO, V.H.P. Controle biológico de pulgões ou afídeospraga em cultivo protegido. Informe Agropecuário, v.28, p.9-17, 2005.

CARNEVALE, A.B. et al. Parasitismo e desenvolvimento de Lysiphlebus testaceipes (Cresson) (Hymenoptera: Aphidiidae) em Aphis gossypii Glover e Myzus persicae (Sulzer) (Hemiptera: Aphididae). Neotropical Entomology, v.32, p.293-297, 2003. Available from: $<$ http://www.scielo.br/scielo.php?script=sci_arttext\&pid=S1519566X2003000200015\&lng=en\&nrm=iso>. Accessed: Aug. 10, 2010. doi: 10.1590/S1519-566X2003000200015.

FERNANDES, A.M.V. et al. Desenvolvimento do pulgão Aphis gossypii Glover (Hemiptera: Aphididae) em três cultivares do algodão herbáceo Gossypium hirsutum L. r. latifolium Hutch. Neotropical Entomology, v.30, p.467-470, 2001. Available from: <http:// w w w. s c i e 1 o.b r / s c i e lo.p h p ? p i d = S 1519 566X2001000300021\&script $=$ sci_arttext $>$. Accessed: Aug. 10, 2010. doi: 10.1590/S1519-566X2001000300021.

FERNANDES, A.M.V. et al. Ocorrência de Aphelinus gossypii Timberlake (Hymenoptera: Aphelinidae) parasitando Aphis gossypii Glover (Hemiptera: Aphididae) em algodão no Estado de Pernambuco. Anais da Sociedade Entomológica do Brasil, v.29, p.831-834, 2000. Available from: <http:// w w w. s c i e 1 o. b r / s c i e 1 o. p h p ? p i d = S 0301 80592000000400026\&script=sci_arttext $>$. Accessed: Aug. 10, 2010. doi: 10.1590/S0301-80592000000400026.

PEÑA-MARTINEZ, R. Biología de afidios y su relación com la transmisión de vírus. In: URIAS, M.C. et al. Afidios como vectores de vírus em México. México: Centro de Fitopatología, 1992. 135p.

RODRIGUES, S.M.M.; BUENO, V.H.P. Parasitism rates of Lysiphlebus testaceipes (Cresson) (Hym.: Aphidiidae) on Schizaphis graminum (Rond.) and Aphis gossypii Glover (Hem.: Aphididae). Neotropical Entomology, v.30, p.625-629, 2001. Available from: <http://www.scielo.br/scielo.php?script=sci_arttext\&pid=S1519566X2001000400017\&lng=en\&nrm=iso\&tlng=en>. Accessed: Aug. 10, 2010. doi: 10.1590/S1519-566X2001000400017.

RODRIGUES, S.M.M. et al. Tabela de vida de fertilidade de Lysiphlebus testaceipes (Cresson, 1880) (Hymenoptera, 
Aphidiidae) em Schizaphis graminum (Rondani, 1852) (Hemiptera, Aphididae). Revista Brasileira de Entomologia, v.47, p.637-642, 2003. Available from: <http://www.scielo.br/ scielo.php? script=sci_arttext\&pid=S 0085 56262003000400017\&lng=en\&nrm=iso $>$. Accessed: Aug. 10, 2010. doi: 10.1590/S0085-56262003000400017.

SILVA, J.S. et al. Tabela de vida de fertilidade de Lysiphlebus testaceipes (Cresson) (Hymenoptera, Braconidae, Aphidiinae) em Rhopalosiphum maidis (Fitch) e Aphis gossypii Glover (Hemiptera, Aphididae). Revista Brasileira de Entomologia, v.52, p.124-130, 2008. Available from: <http://www.scielo.br/ scielo.php? s cript = s ci_art text \& pid=S 0085 56262008000100021>. Accessed: Aug. 10, 2010. doi: 10.1590/ S0085-56262008000100021.
SOARES et al. Progresso no manejo integrado de pragas do algodoeiro no oeste baiano. Campina Grande: Embrapa Algodão, 2003. 3p. (Comunicado Técnico, 194).

STARÝ, P. et al. Environmental research on aphid parasitoid biocontrol agents in Chile (Hym., Aphidiidae; Hom., Aphidoidea). Journal of Applied Entomology, v.115, p.292-306, 1993. Available from: <http://onlinelibrary.wiley.com/doi/10.1111/ j.1439-0418.1993.tb00394.x/abstract>. Accessed: Aug. 10, 2010. doi: 10.1111/j.1439-0418.1993.tb00394.x.

STARÝ, P. et al. Aphid parasitoids (Hymenoptera, Braconidae, Aphidiinae) and their associations related to biological control in Brazil. Revista Brasileira de Entomologia, v.51, p.107118, 2007. Available from: <http://www.scielo.br/ scielo.php? script $=$ sci_arttext \& pid $=$ S $0085-$ 56262007000100018\&lng=en\&nrm=iso>. Accessed: Aug. 10, 2010. doi: 10.1590/S0085-56262007000100018. 